\title{
PERBEDAAN HASIL BELAJAR MELALUI PENERAPAN MODEL INKUIRI TERBIMBING DAN STUDENT TEAM ACHIEVEMENT DIVISIONS PADA PELAJARANILMU PENGETAHUAN ALAM
}

\author{
Rais Hidayat ${ }^{1}$ Ristinofa $S^{2}$ \\ ${ }^{1}$ Dosen Fakultas Keguruan dan Ilmu Pendidikan Universitas Pakuan \\ ${ }^{2}$ Prodi Pendidikan Guru Sekolah Dasar Universitas Pakuan \\ Korenpondensi: rais72rais@gmail.com
}

\section{ARTICLE INFO}

Article History:

Accepted 20 Maret 2017

Available online 17 April 2017

Keywords:

Learning Outcomes, Guided Inquiry, Student Teams Achievement Divisions Model

\begin{abstract}
This research aims to improve the quality of the learning process and the result of learning process Thisresearch is a quasi experimental study. This research subject is class gared IV-A, IV-B and IV-C Public Elementary School Manggis Cicurug Sukabumi. Analysis technique used for pre-requisites analysis test which includes normality test, homogenity test, and hypothesis test using $t$-test. In the normality test with liliefors test showed that the class experiment 1 Ltestvalue is $(0,144)$ with Ltable of $(0,149)$, the class experiment 2 Ltestvalueis $(0,074)$ with Ltable of $(0,154)$, while the control class Ltestvalue is $(0,151)$ with Ltable of $(0,161)$, so that the value of Ltestfor all data $\leq$ than the value of Ltable with the significant standard is $a=0,05 \%$, all data gives normal distribution. In the homogeneity with bartlett test Xtest value is $(3,208) \leq$ with Xtable of $(5,991)$. In the hypothesis test with t-test showed that the class experiment 1 and the control class ttestvalue is $(14,12)$

$\geq$ than ttable of $(1,99394)$, the class experiment 2 ant the control class ttestvalue is $(9,96) \geq$ than ttable of (1,99962), while the class experiment 1 and the class experiment 2 ttestvalue is $(2,83) \geq$ than ttable of $(1,99656)$, therefore all the data showed that $\mathrm{HO}$ rejected and $\mathrm{Ha}$ accepted. Based on this research, it can be concludedthat there are differences of result between the using cooperative learning model guided inquiry and student teams achievement divisions.
\end{abstract}




\section{PENDAHULUAN}

Pendidikan adalah aspek terpenting dalam meningkatkan kehidupan suatu bangsa. Melalui pendidikan kita dapat membentuk sumber daya manusia menjadi lebih baik dan dapat berguna bagi kehidupan kita dimasa depan. Pendidikan merupakan faktor utama dalam pembentukkan pribadi manusia, pendidikan sangat berperan dalam membentuk baik atau buruknya kepribadian manusia tersebut.

Guru adalah salah satu hal yang berperan penting dalam proses pembelajaran. Baik atau buruknya hasil belajar yang ada itu tergantung pada kemampuan seorang guru dalam melaksanakan pembelajaran didalam kelas. Guru memiliki tanggung jawab yang besar atas ketercapaian tujuan pembelajaran yang berlangsung disekolah. Oleh sebab itu guru amat menentukan keberhasilan proses pembelajaran dikelas. Guru harus memiliki kreativitas yang sangat tinggi dalam menjalankan proses pembelajaran agar suasana pembelajaran didalam kelas lebih bervariasi dan tidak monoton, sehingga dapat menimbulkan rasa ingin tahu siswa terhadap mata pelajaran yang akan dipelajari.

Ilmu Pengetahuan Alam (IPA) merupakan kumpulan pengetahuan tentang obyek atau gejala alam yang telah diuji kebenarannya. IPAmencakup dua aspek yaitu sebagai proses yang dikenal dengan metode ilmiah, dan IPA sebagai produk yang dikenal sebagai tubuh pengetahuan (body of knowledge). Produk yang dimaksud adalah fakta-fakta, prinsip-prinsip, model-model dan hukum-hukum alam.

Berdasarkan hasil wawancara dan studi dokumentasi yang telah dilakukan terhadap siswa kelas IV semester 1 tahun pelajaran 2016/2017 Sekolah Dasar Negeri Manggis Kecamatan Cicurug Sukabumi, menyatakan bahwa kualitas hasil belajar ilmu pengetahuan alam siswa masih rendah. Hal tersebut dapat dilihat dari nilai Kriteria Ketuntasan Minimum (KKM) yang telah ditetapkan yaitu 68.Adapun dari 98 siswa, hanya 65 siswa atau $55 \%$ yang mendapatkan nilai diatas KKM sedangkan yang mendapatkan nilai dibawah KKM sebanyak 33 atau $45 \%$ siswa. Dengan demikian masih harus dicari alternatif untuk meningkatkan hasil belajar siswa.

Rendahnya hasil belajar siswa dalam pembelajaran ilmu pengetahuan alam di SD Negeri Manggis Cicurug Sukabumi bukan semata-mata karena materinya yang sulit, tetapi juga dipengaruhi oleh berbagai faktor-faktor lainnya, seperti persepsi awal siswa yang beranggapan bahwa pembelajaran ilmu pengetahuan alam itu membosankan dan kurang termotivasi selama mengikuti proses pembelajaran ilmu pengetahuan alam berakibat terhadap rendahnya hasil belajar.

Selain itu, Saat ini salah satu permasalahan mendasar yang dihadapi pendidikan di Indonesia adalah berkenaan dengan penyelenggaraan kegiatan belajar mengajar yang masih belum efektif sehingga belum dapat menciptakan kegiatan belajar. Dalam proses pembelajaran di sekolah, sebagian besar belum menciptakan suasana belajar 
siswa yang aktif, terlihat dengan adanya guru yang masih banyak mengajar dengan menggunakan model konvensional dimana guru hanya menerapkan metode ceramah disertai dengan tanya jawab dan latihan soal-soal, kurangnya penggunaan media, contoh-contoh yang diberikan hanya terpaku pada buku sehingga dengan suasana pembelajaran seperti itu, membuat siswa menjadi pasif dalam menerima pelajaran. Siswa hanya duduk, mendengarkan dan mencatat materi yang diberikan oleh guru sehingga proses pembelajaran yang dilaksanakan tidak menarik, membosankan dan kurang menarik perhatian siswa dan akhirnya pembelajaran menjadi tidak efektif, hal inilah yang menyebabkan rendahnya hasil belajar siswa.

Maka dari itu Guru harus dapat melaksanakan proses pembelajaran dengan situasi yang menyenangkan dan dapat mengaktifkan peranan siswa dalam pembelajaran agar siswa aktif, bersemangat dan tertarik dalam pembelajaran, karena kondisi belajar yang monoton dan kurang kondusif akan membuat siswa kurang tertarik dan kurang termotivasi dalam pembelajaran yang berdampak pada hilangnya konsentrasi belajar siswa yang akan berakibat pada rendahnya hasil belajar siswa.

Upaya yang dapat dilakukan adalah dengan penggunaan model pembelajaran yang tepat dan sesuai dengan konsep-konsep materi yang diajarkan dan karakteristik siswa sekolah dasar. Dengan menggunakan model pembelajaran dalam proses pembelajaran bertujuan agar proses pembelajaran tidak monoton, mampu melibatkan siswa secara aktif dan untuk meningkatkan hasil belajar siswa itu sendiri.

Model pembelajaran yang dirasa tepat dan sesuai untuk meningkatkan pemahaman siswa pada materi rangka dan alat indra manusia adalah model pembelajaran inkuiri terbimbing dan model pembelajaran Student Team Achievement Divisions. Kedua model tersebut merupakan model pembelajaran yang menciptakan suasana kelas yang menyenangkan dengan mengaktifkan peranan siswa dalam proses pembelajaran, siswa dapat berfikir logis dan belajar dengan gaya belajarnya sendiri kemudian siswa bekerja sama dalam kelompok-kelompok kecil secara heterogen sehingga siswa lebih aktif dalam belajar.

Model pembelajaraan inkuiri terbimbing merupakan model pembelajaran yang memilikikeunggulandiantaranyaadalahdalammembuat siswa berfikir secara logis dan siswa mampu menyimpulkan sendiri apa yang telah mereka pelajari. Selain itu model pembelajaran ini diharapkan dapat meningkatkan keaktifan yang berpengaruh pada tercapainya hasil belajar siswa karena interaksi antara siswa itu sendiri baik secara fisik maupun psikologi dapat ditingkatkan.

Model pembelajaran Student Team Achievement Divisionsmerupakan model pembelajaran kelompok dengan tujuan agar siswa dapat saling bekerja sama, bertanggung jawab dengan kelompoknya, saling membantu memecahan masalah, 
saling menjelaskan satu sama lain. Model ini juga melatih siswa untuk bersosialisasi dengan baik dan membuat kelas semakin hidup.

Berdasarkan uraian di atas, maka peneliti berkeinginan untuk mengadakan suatu penelitian dengan judul Perbedaan Hasil Belajar Kognitif Melalui Model Pembelajaran Inkuiri Terbimbing dan Model Pembelajaran Student Team Achievement Divisions pada Mata Pelajaran Ilmu Pengetahuan Alamtentang cerira rakyrangka dan alat indra manusiapada siswa kelas IVA, IVB, dan IVC Sekolah Dasar Negeri Manggis Kecamatan Cicurug Kabupaten Sukabumi Pelajaran 2016/2017.

Berdasarkan latar belakang masalah, identifikasi masalah dan pembatasan masalah, maka perumusan masalah dalam penelitian sebagai berikut :

1. Apakah terdapat perbedaan antara model pembelajaran inkuiri terbimbing dengan model konvensional terhadap hasil belajar kognitif mata pelajaran IPA di kelas IV Sekolah Dasar Negeri Manggis Girang Kecamatan Cicurug Kabupaten sukabumi semester ganjil tahun pelajaran 2016-2017?

2. Apakah terdapat perbedaan antara model pembelajaran STAD (Student Team Achievement Divisions) dengan model konvensional terhadap hasil belajar kognitif pada mata pelajaran IPA di kelas IV Sekolah Dasar Negeri Manggis Girang Kecamatan Cicurug Kabupaten Sukabumi semester ganjil tahun pelajaran 2016-2017?

3. Apakah terdapat perbedaan hasil belajar kognitif pada mata pelajaran IPA melalui model pembelajaran inkuiri terbimbing dan STAD (Student Team Achievement Divisions) dengan model pembelajaran konvensional pada siswa kelas IV Sekolah Dasar Negeri Manggis Girang Kecamatan Cicurug Kabupaten Sukabumi semester ganjil tahun pelajaran 2016-2017?

\section{KAJIAN PUSTAKA}

\section{Hasil Belajar}

Belajar merupakan Suatu aktivitas yang kompleks yang terjadi secara terus menerus pada semua orang dan berlangsung seumur hidup yang salah satu tandanya yaitu adanya proses perubahan tingkah laku, Perubahan tingkah laku tersebut disebut dengan hasil belajar. Hasil belajar merupakan proses perubahan tingkah laku siswa setelah ia mengalami proses belajar. Hal ini didukung oleh Purwanto (2013: 54) mengatakan bahwa hasil belajar adalah perubahan yang terjadi setelah mengikuti proses belajar mengajar sesuai dengan tujuan pendidikan. Perubahan merupakan hasil yang telah dicapai dari kegiatan belajar yang telah dilakukan oleh siswa sesuai dengan tujuan pembelajaran yang diharapkan. 
Hasil belajar siswa dapat berupa berbagai kemampuan-kemampuan.Berbagai kemampuan itu adalah kemampuan yang menyangkut aspek kognitif, afektif dan psikomotor. Hal ini diperkuat oleh teori Sudjana (2010: 23) yang mengemukakan bahwa Hasil belajar adalah kemampuan-kemampuan yang dimiliki siswa setelah ia menerima pengalaman belajarnya. Kemampuan itu termasuk kemampuan kognitif, Afektif dan psikomotor.

Suprijono (2013: 5) mengemukakan hasil belajar adalah pola-pola perbuatan, nilainilai, pengertian-pengertian, sikap-sikap, apresiasi dan keterampilan. Dari beberapa pernyataan tersebut dapat disimpulkan bahwa hasil belajar adalah kemampuan yang dimiliki siswa dan segala sesuatu yang menjadi milik siswa setelah proses belajar mengajar.

Hasil belajar merupakan perubahan tingkah laku melalui perubahan kognitif, afektif dan psikomotor. Hal ini sependapat dengan Susanto (2013: 5) yang menyatakan bahwa hasil belajar yaitu perubahan-perubahan yang terjadi pada diri siswa, baik yang menyangkut aspek kognitif, afektif, dan psikomotor sebagai hasil dari kegiatan belajar.

Sudiyarto dalam Waluyo, dkk (1987: 2) menyebutkan bahwa hasil belajar adalah tingkat penguasaan yang dicapai oleh siswa dalam mengikuti program belajar mengajar sesuai dengan tujuan pendidikan yang ditetapkan.

Berdasarkan pendapat para ahli di atas, dapat dipahami hasil belajar hasil adalah suatukemampuan yang dimiliki seorang siswa setelah mereka menerima pembelajaran atau penilaian akhir dari proses pembelajaran dan pembentukan tingkah laku dari seorang siswa, yang dilakukan secara berulang-ulang.

\section{Model Inkuiri Terbimbing}

Pembelajaran Inkuiri Terbimbing merupakan salah satu tipe pembelajaran yang dalam proses pelaksanaannya siswa terlibat secara langsung dalam proses pembelajaran. Sanjaya (2009: 126) yang mengungkapkan bahwa inkuiri merupakan upaya mengimplementasikan rencana yang sudah disusun dalam kegiatan nyata agar tujuan yang telah disusun tercapai secara optimal.Keberhasilan pembelajaran tidak terlepas dari pemilihan model yang tepat. Kriteria yang digunakan dalam pemilihan model antara lain: kesesuaiannya dengan tujuan, kondisi kelas/sekolah, tingkat perkembangan dan kebutuhan siswa, kemampuan guru dalam menggunakan model, dan alokasi waktu yang tersedia. Inkuiri berasal dari bahasa Inggris "inquiry”, yang secara harfiah bararti penyelidikan.

Pendapat lain yang dikemukakan oleh Anam (2015: 7) berpendapat inkuiri merupakan model belajar mengajar, siswa ditempatkan sebagai subjek pembelajaran, yang berarti bahwa siswa memiliki andil besar dalam menentukan suasana dan model 
pembelajaran. Dalam model ini, setiap peserta didik di dorong untuk terlibat aktif dalam proses belajar mengajar, salah satunya dengan secara aktif mengajukan pertanyaan yang baik terhadap setiap materi yang disampaikan. Piaget dalam mulyasa (2006:108) mengemukakan bahwa model inkuiri merupakan model yang mempersiapkan siswa pada situasi untuk melakukan eksperimen sendiri secara luas agar melihat sesuatu yang terjadi, ingin melakukan sesuatu, mengajukan pertanyaan- pertanyaan, dan mencari jawabannya sendiri, serta menghubungkan penemuan yang satu dengan penemuan yang lain, membandingkan sesuatu yang ditemukannya dengan yang ditemukan siswa lain.

Sementara Hanafiah \& Suhana (2009: 77) mengungkapkan bahwa pembelajaran inkuiri merupakan rangkaian kegiatan pembelajaran yang melibatkan secara maksimal seluruh kemampuan siswa untuk mencari dan menyelidiki secara sistematis, kritis dan logis sehingga mereka dapat menemukan sendiri pengetahuan, sikap dan keterampilan sebagai wujud adanya perubahan perilaku. Inkuiri Terbimbing bisa dikatakan suatu kegiatan pembelajaran dimana prosesnya dibantu dengan bimbingan guru. Pendapat lain yang dikemukakan oleh La Iru \& Arihi (2012:15) guru harus membimbing dan membantu siswa untuk mengidentifikasi pertanyaan, dan masalahmasalah, membantu siswa dalam menemukan sumber informasi yang tepat, dan membimbing siswa dalam melakukan penyelidikan. Model pembelajaraan inkuiri terbimbing adalah model pembelajaranyang dalam pelaksanaannya siswa terlibat langsung dalam pembelajaran sehingga siswa menjadi subjek dan guru membimbing siswa untuk mencapai tujuan pembelajaran.

\section{Model Student Team Achievement Divisions}

Model pembelajaran kooperatif Student Team Achievement Divisions adalah salah satu model yang digunakan di Sekolah Dasar. Model pembelajaran kooperatif Student Team Achievement Divisions yaitu model pembelajaran kooperatif yang dikembangkan oleh Slavin yaitu belajar kelompok dengan mengendalikan kelompok prestasi. Model pembelajaran ini dilakukan dengan cara mengelompokkan siswa secara heterogen, dan siswa yang pandai menjelaskan ke anggota yang lain sampai mengerti, Tampubolon (2014: 96).

Menurut Hidayat (2011: 95) Student TeamAchievement Divisions (STAD) merupakan salah satu model pembelajaran kooperatif yang efektif dan sederhana, baik untuk guru yang baru mulai menggunakan pendekatan kooperatif dalam kelas. Ngalimun (2014:168) STAD salah satu model pembelajaran kooperatif dengan sintaks pengarahan, buat kelompok heterogen 4-5 orang dan di diskusikan bahan belajar LKS secara kolaboratif, presentasi kelompok sehingga terjadi diskusi kelas dan berikan reward. Sedangkan menurut Shoimin (2014: 185) STAD dikembangkan 
oleh Slavin merupakan pendekatan pembelajaran kooperatif yang paling sederhana. Berdasarkan pendapat para ahli, Model pembelajaran Student Team Achievement Divisions merupakan model pembelajaran kooperatif dimana siswa dikelompokkan lalu saling bekerja sama bersama kelompoknya masing-masing dan bertanggung jawab kepada anggota kelompoknya apabila salah satu teman kelompok nya tidak mengusai materi.

\section{METODOLOGI PENELITIAN}

Penelitian ini akan dilaksanakan di Sekolah Dasar Negeri Manggis Kecamatan Cicurug Kabupaten Sukabumi. Waktu penelitian ini akan dilaksanakan pada semester ganjil tahun pelajaran 2016/2017. Populasi pada penelitian ini adalah seluruh siswa kelas IV di SD Negeri Manggis yang berjumlah 98 siswa. Seluruh siswaakan di ukur sebagai sampel yang oleh karena itu seluruh populasi akan digunakan dalam penelitian.

Metode penelitian yang digunakan dalam penelitian ini adalah eksperimen quasi.Metode eksperimen quasi memiliki kekhasan yang diperlihatkan oleh dua hal, pertama penelitian eksperimen menguji secara langsung pengaruh suatu variable terhadap variable lain, kedua menguji hipotesis hubungan sebab-akibat (Sukmadinata,2010: 194).

Teknik pengumpulan data yang digunakan dalam penelitian ini yakni hasil belajar berupa test objektif pilihan ganda sebanyak 40 soal dengan empat alternatif jawaban yang sebelumnya diuji cobakan untuk menguji validitas dan realibilitas butir soal. Data yang dianalisis adalah skor test yang merupakan hasil belajar siswa dalam mata pelajaran matematika yang dilakukan secara berurutan, sebagai berikut: (1) Memberi skor pada pretest dan posttest untuk mengukur kemampuan kognitif siswa; (2) Menghitung skor N-Gain yang dinormalisasi; (3) Menghitung skor rata-rata dan standar deviasi (SD); (4) Melakukan uji prasyarat analisis dengan uji normalitas, homogenitas, dan hipotesis.

\section{HASIL PENELITIAN}

Deskripsi hasil penelitian dikelompokan menjadi tiga bagian yaitu data hasil belajar kognitif rangka dan alat indra manusia siswa kelompok kelasdengan menggunakan model pembelajaran Inkuiri Terbimbing, data hasil belajar kognitif Rangka dan Alat Indra Manusia kelompok kelas dengan menggunakan model pembelajaran kooperatif Student Team Achievement Divisions, dan data hasil belajar kognitif rangka dan alat indra manusia kelompok kelas dengan menggunakan model pembelajaran konvensional. 
1. Data Hasil Belajar Kognitif tentang Rangka dan Alat Indra Manusia Melalui

Model Pembelajaran Inkuiri Terbimbing.

Berdasarkan data yang diperoleh sebelum siswa mendapatkan pembelajaran dan sesudah siswa mendapatkan pembelajaran dengan menggunakan model pembelajaran kooperatif Inkuiri Terbimbing,maka dilakukan perhitungan $\mathrm{N}$-Gain sehingga diperoleh jumlah skor minimal 29 dan skor maksimal 94.

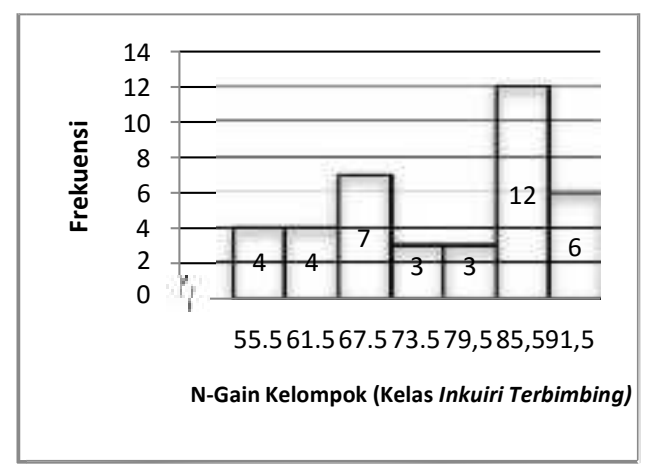

\section{Gambar 1 Histogram Hasil Belajar Mata Pelajaran Ilmu Pengetahuan Alam Melalui Model Pembelajaran Inkuiri Terbimbing}

2. Data Hasil Belajar Kognitif Tentang Rangka dan Alat Indra ManusiaMelalui

Model Pembelajaran Kooperatif Student Team Achievementr Divisions.

Berdasarkan data yang diperoleh sebelum siswa mendapatkan pembelajaran dan sesudah siswa mendapatkan pembelajaran dengan menggunakan model pembelajaran kooperatif Student Team Achievement Divisions maka dilakukan perhitungan $N$-Gain sehingga diperoleh jumlah skor minimal 54 dan skor maksimal 85 .

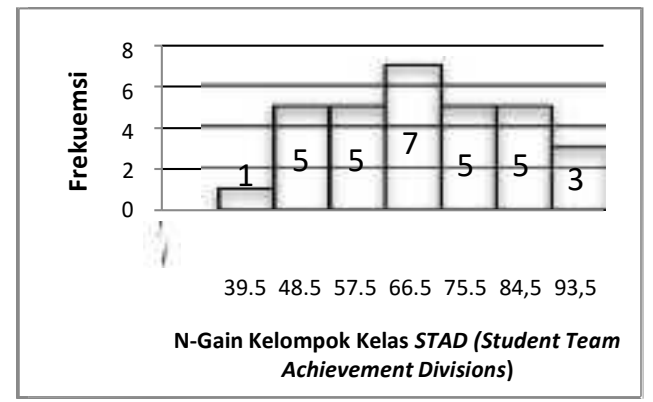

Gambar 2 Histogram Hasil Belajar Mata Pelajaran Ilmu Pengetahuan Alam Melalui Model Pembelajaran Kooperatif STAD (Student Team Achievement Divisions) 
3. Data Hasil Belajar Kognitif Tentang Rangka dan Alat Indra Manusia Melalui

Model Pembelajaran Konvensional.

Berdasarkan data yang diperoleh sebelum dan sesudah siswa menerapkan model pembelajaran konvensional, maka dilakukan perhitungan $\mathrm{N}$-Gain sehingga diperoleh jumlah skor manimal 42 dan skor maksimal 64.

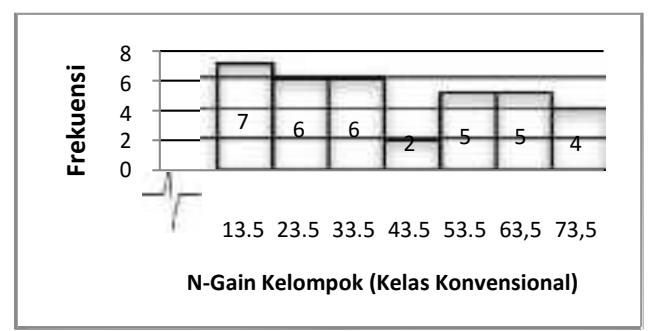

\section{Gambar 3 Histogram Hasil Belajar Mata Pelajaran Ilmu Pengetahuan Alam} Melalui Pembelajaran Konvensional

4. Perbedaan Hasil Belajar Kognitif Tentang Rangka dan Alat Indra manusia Melalui Model Pembelajaran Kooperatif Inkuiri Terbimbing, Model

Pembelajaran Student Team Achievement Divisions, dan Model Pembeljaran Konvensional.

Berdasarkan data skor rata-rata pretest, skor rata-rata posttest dan skor rata-rata $N$-Gain yang diperoleh kelompok kelas Inkuiri Terbimbing, kelompok kelas Student Team Achievement Divisions dan kelompok kelas konvensional terlihat adanya perbedaan pada masing-masing kelompok kelas. Skor rata-rata pretest masing-masing kelompok kelas menunjukan perbedaan yang tidak terlalu

berbeda jauh, kemudian skor rata-rata $N$-Gain masing-masing kelompok kelas menunjukan perbedaan yang relatif besar.

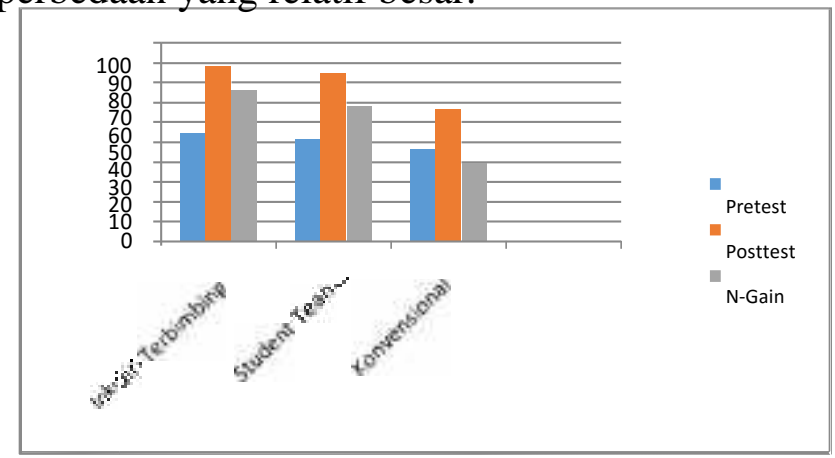

Gambar 4 Histogram Perbedaan Skor Rata-Rata Hasil Belajar Ilmu Pengetahuan Alam Melalui Pembelajaran Konvensional dengan Model Pembelajaran Inkuiri Terbimbing dan STAD (Student Team Achievement Divisions) 


\section{PEMBAHASAN}

Setelah melakukan uji coba instrumen, maka diperoleh 40 butir soal yang valid. Kemudian 35 soal yang valid tersebut dipergunakan untuk soal pretestdan posstest dalam penelitian.

Berdasarkan hasil penelitian yang telah dilakukan, diketahui skor rata-rata $\mathrm{N}$ Gain hasil belajar kognitif tentang rangka dan alat indra manusiaantara ketiga kelas sampel. Sehingga diperoleh perbedaan rata-rata $\mathrm{N}$-Gain hasil belajar kognitiftentang rangka dan alat indra manusia yang signifikan baik antara kelompok kelas inkuiri terbimbing dengan kelompok kelas kontrol, antara kelompok kelas Student Team Achievement Divisionsdengan kelompok kelas kontrol, dan antara kelompok kelas Inkuiri Terbimbing dengan kelompok kelas Student Team Achievement Divisions Berdasarkan nilai rata-rata $N$-Gain kelompok kelas Inkuiri Terbimbing dengan kelompok kelas Student Team Achievement Divisions yaitu berurut-turut 76 dan 68 lebih tinggi dari pada nilai rata-rata $\mathrm{N}$-Gain kelompok kelas kontrol yaitu 39. Setelah dilakukan pengujian hipotesis diperoleh hasil bahwa $\mathrm{H}_{\mathrm{o}}$ ditolak sehingga hiopotesis alternatif $\mathrm{H}_{\mathrm{a}}$ diterima. Hal tersebut menunjukan adanya peningkatan hasil belajar kognitif tentang rangtka dan alat indra manusiakarena penggunaan model pembelajaran pada kelas eksperimen dibandingkan dengan hasil belajar kognitif tentang rangka dan alat indra manusia pada kelas kontrol.

Adapun penelitian ini bertujuan untuk mengetahui perbedaan hasil belajar kognitifmelalui model pembelajaran Inkuiri Terbimbing dan Model pembelajaran Student Team Achievement Divisions, maka pembahasan selanjutnya akan terpusat pada penelitian kelas eksperimen Inkuiri Terbimbing dan kelas eksperimen Student Team Achievement Divisions. Berdasarkan hasil penelitian hasil belajar kognitif tentang rangka dan alat indra manusia menunjukan nilai rata-rata $N$-Gain kelompok kelas Inkuiri Terbimbing sebesar 76 lebih besar dari pada nilai rata-rata $N$-Gain kelompok kelas Student Team Achievement Divisions sebesar 68. Setelah dilakukan uji t nilai rata $N$-Gain kedua kelompok tersebut diperoleh $\mathrm{t}_{\text {hitung }}>\mathrm{t}_{\text {tabel }}$ yaitu 3,18> $1,99656$.

Hal ini dapat menunjukan bahwa terdapat perbedaan hasil belajar kognitif tentang rangka dan alat indra manusia melalui penerapan model pembelajaran Inkuiri Terbimbing dan model pembelajaran Student Team Achievement Divisions.Hasil penelitian ini menunjukan adanya peningkatan hasil belajar kognitiftentang rangka dan alat indra manusia pada kelompok kelas Inkuiri Terbimbingyang lebih tinggi dibandingkan denganhasil belajar kognitiftentang rangka dan alat indra manusia pada kelompok kelas Student Team Achievement Divisions. Hal ini mungkin dikarenakan dalam proses pembelajaran dengan menggunakan model Inkuiri Terbimbingdalam proses pembelajarannnyasiswa menjadi lebih aktif dan menyenangkan sehingga 
pembelajaran menarik karena siswa tidak merasa jenuh dan mampu mengubah persepsi siswa yang awalnya merasa bosan belajar Ilmu Pengetahuan Alam menjadi senang dan nyaman sehingga pembelajaran bermakna dan lebih mudah memahami materi yang disamapaikan.

Penggunaan modelStudent Team Achievement Divisionsyang dalam proses pembelajarannya adanya pembagaian kelompok secara heterogen berdasarkan tingkatan kemampuan akademik siswa, dalam proses pembelajarannya terdapat diskusi secara kelompok dan memberikan kesempatan kepada ketua kelompok untuk menjelaskan kepada anggota kelompoknya yang belum mengerti dan model ini sangat efektif karena model pembelajaran kooperatiif yang paling sederhana.

\section{SIMPULAN}

Berdasarkan pembahasan hasil penelitian yang telah dilakukan, ditarik kesimpulan bahwa terdapat perbedaan hasil belajar kognitif tentang cerita rakyat dengan menggunakan model pembelajaran kooperatif Inkuiri Terbimbing dan model pembelajaran kooperatif Student Team Achievement Divisionspada siswa kelas IVA, IVB dan IVC Sekolah Dasar Negeri Manggis Kecamatan CicurugKapubaten Sukabumi Semester Ganjil Tahun Pelajaran 2016/2017.

Simpulan di atas sesuai dengan hasil penelitian sebagai berikut:

1. Terdapat perbedaan hasil belajar Ilmu Pengetahuan Alam dengan menggunakan model pembelajaran Inkuiri Terbimbing dengan nilai rata-rata pretest sebesar 54,44 dan posttest sebesar 88,15 dengan ketuntasan hasil belajar sebesar 92,14\% sedangkan model pembelajaran konvensional dengan nilai pretest sebesar 46,18 dan postest sebesar 66,47 dengan ketuntasan hasil belajar sebesar 50,66\%.

2. Terdapat perbedaan hasil belajar Ilmu Pengetahuan Alam dengan menggunakan model pembelajaran kooperatif Student Team Achiement Divisionsdengan nilai rata-rata pretest sebesar 51,51 dan posttest sebesar 84,54 dengan ketuntasan hasil belajar sebesar 85,92\% sedangkan model pembelajaran konvensional dengan nilai pretest sebesar 46,18 dan postest sebesar 66,47 dengan ketuntasan hasil belajar sebesar $50,66 \%$.

3. Terdapat perbedaan hasil belajar Ilmu Pengetahuan Alam dengan menggunakan model pembelajaran Inkuiri Terbimbing dengan nilai rata-rata pretest sebesar 54,44 dan posttest sebesar 88,15 dengan ketuntasan hasil belajar sebesar 92,14\% sedangkan model pembelajaran Student Team Achiement Divisionsdengan nilai rata-rata pretest sebesar 51,51 dan posttest sebesar 84,54 dengan ketuntasan hasil belajar sebesar $85,92 \%$. 


\section{DAFTAR PUSTAKA}

Anam, Khoirul. 2015. Pembelajaran Berbasis Inkuiri. Yogyakarta: Pustaka Pelajar.

Hanafiah, Nanang, dan Suhana. 2009. Konsep Strategi Pembelajaran. Bandung : Refika Aditama.

Hidayat, Ujang. 2011. Model-Model Pembelajaran Berbasis Paikem. Bandung : CV. Siliwangi.

La iru dan Arihi, La Ode Safiun. 2012. Analisis Penerapan Pendekatan, Metode, Strategi, dan Model-Model Pembelajaran. Jogjakarta : Multi Presindo.

Ngalimun. 2014. Strategi dan Model Pembelajaran. Yogyakarta : Aswaja Pressindo.

Purwanto. 2013. Evaluasi Hasil Belajar. Yogyakarta : Pustaka Pelajar.

Sanjaya, Wina. 2009. Strategi Pembelajaran. Jakarta : Kencana Prada Media.

Sanjaya, Wina. 2013. Kurikulum Pembelajaran : Teori dan Praktik Pengembangan Kurikulum Tingkat Solusi Pendidikan (KTSP). Jakarta:Perpustakaan Nasional.

Sudjana, Nana. 2010. Penilaian Hasil Proses Belajar Mengajar. Bandung : PT Remaja Rosdakarya.

Suprijono, Agus. 2013. Cooperative Learning TEORI \& APLIKASI PALKEM. Yogyakarta: Pustaka Belajar.

Susanto, Ahmad. 2013. Teori Belajar dan Pembelajaran di Sekolah Dasar. Jakarta : Prenandamedia Grup.

Tampubolon, Saur. 2014. Penelitian Tindakan Kelas. Jakarta : Erlangga

Waluyo dkk, 1987. Penilaian Pencapaian Hasil Belajar. Jakarta : Karunika Jakarta Universitas Terbuka. 